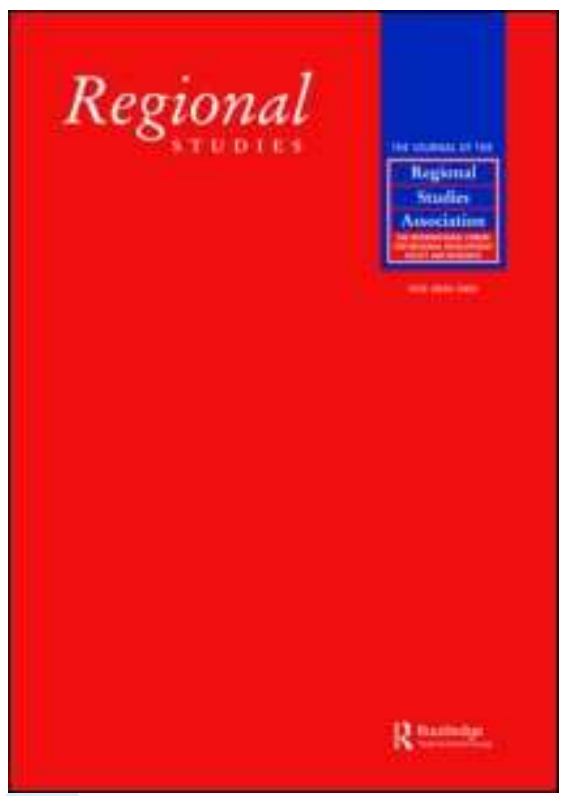

\title{
Key Worker Housing, Welfare Reform and the New Spatial Policy in England
}

\begin{tabular}{|r|l|}
\hline Journal: & Regional Studies \\
\hline Manuscript ID: & CRES-2006-0136.R2 \\
\hline Manuscript Type: & Main Section \\
\hline JEL codes: & $\begin{array}{l}\text { R58 - Regional Development Policy < R5 - Regional Government } \\
\text { Analysis < R - Urban, Rural, and Regional Economics }\end{array}$ \\
\hline Keywords: & spatial policy, social policy, housing, key workers, competitiveness \\
\hline & \\
\hline
\end{tabular}

\section{SCHOLARONE Manuscripts}


Key Worker Housing, Welfare Reform and the New Spatial

Policy in England

\author{
By \\ Mike Raco \\ Department of Geography \\ King's College London \\ The Strand \\ London, WC2R 2LS \\ Email: $\underline{\text { mike.raco@kcl.ac.uk }}$
}

February 2007 


\begin{abstract}
Under the Labour government the character of spatial policy in England has been subject to significant change. The emphasis has increasingly been on spatial policy as an active social policy. This paper uses the example of public sector key worker housing programmes in England to exemplify and analyse the character of these changes. It argues that the new approach also contains an explicit recognition that social policies can and should be reoriented towards the wider objectives of accumulation and competitiveness and this has broader implications for the organisation and character of the welfare state.
\end{abstract}

Key Words: Spatial Policy, Social Policy, Housing, Key Workers, Competitiveness 


\section{Introduction}

The form and character of British spatial policy has undergone significant changes since the late 1970s. The Keynesian principles of direct state intervention in the economy have given way to a new set of concerns with the competitiveness of autonomous places and the firms and entrepreneurs within them. These philosophies, established under the Thatcher and Major governments of the 1980s and 1990s, have been extended and expanded since 1997 by a Labour administration that has increasingly focused on the 'needs' of producers within the economy and how their productivity and competitiveness can best be supported (see Brown, 2006). As a part of this reconceptualisation of the objectives and the means of spatial policy, there has also been a growing focus on the broader social and environmental contexts in which economic development is taking place. The concept of sustainability, for example, has become more prevalent during the 2000s with its emphasis on the provision of 'quality environments' and the availability and accessibility of the means of social consumption for a broad range of social groups (see While et al, 2004; Whitehead, 2006). It is increasingly argued that in the more 'competitive' regions of the country the lack of available housing and growing supply-side pressures on other infrastructure and welfare services is beginning to undermine both the competitiveness of producers and the longer-term economic and social sustainability of communities. Spatial policy's role is to identify such pressures and use a variety of policy initiatives to tackle them.

This paper draws on two inter-related research projects to examine the implementation and politics of a significant spatial policy initiative that has emerged during the 2000s, namely housing support for so-called 'key workers'. It assesses the aims and objectives of such programmes and the extent to which they reflect and reproduce recent changes in the core rationalities and priorities of spatial policy and their relationship to broader questions concerning state regulation and competitiveness policy. The conceptualisation of the 'key worker', it argues, draws on particular interpretations about what it is that makes a place 'competitive', whose presence is necessary for the socio-economic sustainability of a region, and the relationships between modes of production and social consumption. During the 2000s key worker definitions have reflected practical concerns over issues such as changing labour market conditions, the quality and sustainability of welfare services such as health and education, and the supply of available and affordable housing. They have also reflected politically constructed imaginations concerning the value of particular types of work and workers to the competitiveness of places. As such the emergence of key worker support is indicative 
of how welfare and social policies are being re-configured in new ways to support new forms of economic competitiveness and growth in the name of sustainability and sustainable community-building.

The paper begins by outlining some of the core debates surrounding the changing rationalities of spatial policy in the UK and the nature of the shift towards sustainability and welfare-consumption based agendas. It then turns to the government's KW housing programmes in London and the South East. It begins by outlining the programmes that have been introduced and their influence on housing and public service labour markets. It then explores their rationalities, objectives and characteristics before assessing their wider impacts and social, economic, and political implications. Collectively, the paper argues such programmes exemplify the ways in which spatial policy under the Labour government has primarily become a new field of active social policy (cf. Cochrane, 2003; 2006).

\section{Social Policy, Collective Consumption and the New Spatial Policy}

During the 1990s it became increasingly difficult to identify a set of direct policy initiatives that could be characterised as a 'spatial policy'. With the waning of the post-war settlement, and its concern with the ordered national and regional distribution of industry and labour, spatial policy interventions became increasingly fragmented and un co-ordinated (see Brenner, 2003). Under the Thatcher governments of the 1980s, the whole concept of 'spatial planning' became discredited and its legitimacy was undermined (see Allmendinger and Tewdwr-Jones, 2006). The introduction of the Single Regeneration Budget and the redrawing of the Regional Selective Assistance map under the Major administration of the mid 1990s represented a new, more flexible approach to area-based initiatives and this trend was mirrored during the first years of the Labour government in which numerous policy initiatives and projects were launched (see Imrie and Raco, 2003).

However, during the 2000s there has been a clear shift in emphasis with spatial policy and planning once again becoming a key stated priority of government. Some identifiable trends in this new spatial policy thinking have also emerged. First, there has been a new focus on the mobility and attraction of particular socio-economic groups. Under the influence of authors such as Richard Florida's (2004), policy interventions at national, regional, and local scales have become increasingly concerned with the presence and availability of highly skilled, young, professional workers (see Peck, 2005). It is argued that such workers not only play a 
necessary role in generating new forms of economic growth and dynamism but also help foster new political cultures of openness, tolerance, and creativity. It is also argued, however, that these highly skilled individuals are scarce and possess a relatively high degree of mobility making them increasingly difficult to attract and retain (see The Economist, 2006a; 2006b). One of the core objectives for emerging spatial policy is, therefore, to enhance the attractiveness of places to such workers in order to influence their locational decisions.

A second related trend in policy thinking concerns the broader shift in focus towards new forms of sustainability and broader questions over the availability of collective consumption, liveability, and quality of life. The current policy emphasis on creating 'sustainable communities' ostensibly reflects more holistic approaches to regional and urban planning (see Office of the Deputy Prime Minister, 2004; Pacione, 2004). The new priorities concentrate on the creation of liveable, balanced places in which the quality of life enjoyed by residents is relatively high and is supported by broad range of public and private services. Place-making and community-building have become the new buzzwords of policy thinking (see CABE, 2006; DCMS, 2006). These have been ostensibly supported by a range of new initiatives including the Sustainable Communities: Building For the Future Plan launched in 2003 (ODPM, 20031), a new series of Planning Policy Statements to re-focus the planning system, (including the publication of Planning Policy Statement 1: Planning for Sustainable Development (ODPM, 2004a)), and programmes such as the Mixed Communities Initiative (ODPM, 2005) and Section 106 agreements in which local authorities are empowered to negotiate for significant planning gains from private sector developers.

Taken together, the new spatial policy therefore has to be conceptualised in rather different terms from the redistributive policy frameworks that were established after the war. As Cochrane (2003) argues, it now consists of an active social policy principally developed in and through changes to wider welfare state programmes and agendas. This involves a broader shift in emphasis in state policy and regulation from the provision of direct support to producers, primarily in Development Areas, to a broader concern with how the conditions for economic competitiveness can be sustained and enhanced through welfare policy interventions in fields such as housing, skills development, and health service provision. New forms of capitalist accumulation are perceived to be dependent upon the existence of functioning and productive labour markets, communities, and social services. Moreover, this provision needs

\footnotetext{
${ }^{11}$ The DCLG assumed the functions of the now defunct Office of the Deputy Prime Minister (ODPM) in May 2006.
} 
to be available to a sufficient spectrum of citizens and workers in order to enable social consumption and reproduction to take place in a manner that sustains new forms economic of economic dynamism.

This re-characterisation of spatial policy as an active social policy has significant political implications. It requires that new processes of selection are established in which the 'needs' of different social groups are identified and their mobility and fixity channelled so that the right people are located in the right places, at the right times to support and reproduce the economic competitiveness of places and regions. The emphasis is not only on the presence and/or absence of private sector entrepreneurs and the 'creative class' but also on the broader operation of public services and the location and distribution of appropriately skilled workers to sustain those services. Spatial policy becomes explicitly concerned with the creation of spatial fixes in which the needs of production and social reproduction are brought together and met in place or 'institutional sites at which place and space intersect' (Peck, 1996: p.16). In many ways the implementation of recent programmes such as the Sustainable Communities Plan (ODPM, 2003) reflect a new era of spatial policy, one concerned with limiting or controlling the effects of economic growth and engaging directly with the relationships between production and consumption (see While et al, 2004). This qualitative shift in spatial policy thinking, in turn, involves a greater concern with the location and accessibility of labour and the relationships between where people (and workers) live and welfare service provision and competitiveness.

And yet, despite the emergence of these new rationalities and ways of thinking about spatial policy, its priorities, and its objectives, there remain significant unanswered questions about its implementation and wider significance. To date, the Sustainable Communities Plan remains more of a set of imagined aspiration rather than a clear programme of action. Development agencies at different scales are unsure about how to change their own priorities and ways of working in order to meet the new priorities (see Raco, 2007a). At the same time the new spatial policy raises political dilemmas. In many ways the new agendas invert old spatial policy priorities by focusing on the needs of areas such as Greater London and the South East in which growth pressures are most acute and where there is greatest pressure on social and environmental resources (see While et al, 2004). It is in such places that the need for social policy interventions in order to sustain economic competitiveness and communitybuilding is greatest. This has obvious implications for spatial and social justice. 
In addition, the new focus on workers as both the subjects and the objects of policy raises a series of questions about policy priorities and outcomes. Which workers and citizens, for example, are essential to the competitiveness of sustainable places? How should they be defined and how should their mobility (and fixity) be influenced by policy? The process of selection and support for particular groups in the name of 'sustainability' or 'spatial policy' is potentially divisive and involves the differential treatment of different groups of more and less 'valuable' workers and citizens. The new approach also contains an explicit recognition that social policies can and should be re-oriented towards the wider objectives of accumulation and competitiveness and this has broader implications for the organisation, form and character of the welfare state.

It is in this wider context that key worker housing policies have been re-introduced in the fast-growing regions of London, the South East, and the East of England. The remainder of the paper examines the aims, objectives, and rationalities of the new programmes and the wider politics that have surrounded their introduction and expansion. The discussion illuminates broader debates over: imaginations of what it is that makes a place 'competitive' and 'sustainable'; the links between economic competitiveness and the availability of social consumption assets, such as housing; the new politics and rationalities of spatial development; and changing modes of welfare entitlement and state selection. The research material used in this paper comes from a range of sources and was collected during the period 2004-2006. The first stage of data collection involved the research and analysis of documents and records from archival sources, including UK government records such as the National Archives in London. Subsequent archival research examined the minutes and records of organisations involved in key worker housing policy-making and delivery, the policy frameworks themselves, relevant speeches and policy statements, and other sources of qualitative evidence. These were supplemented by twenty semi-structured interviews with policy officials, civil servants, workers representatives, and other actors involved in the development and delivery of key worker and spatial policy. Interviewees were selected from key sectors/organisations including the Department of Communities and Local Government, a range of Trade Unions representatives, including the Trades Union Congress, representatives of development agencies and local authorities in London and the South East of England. 
The re-emergence of the key worker and the changing character of spatial policy

The mobilisation of 'key workers' (KWs) within spatial policy is nothing new. The Distribution of Industry Act 1945, for example, extended wartime labour market measures and gave grants to certain KWs to facilitate their movement from the South and East of England to the Development Areas of the North and West (see Raco, 2006; 2007b). These KWs were primarily private sector managers or those in specialised and skilled manufacturing professions whose presence or absence in particular places was seen as critical to the effectiveness of development programmes. Overall, the experiences of post-war KW policies were indicative of the wider limitations of regional policy. There were significant difficulties in defining exactly who constituted a KW and policy implementation was often erratic and poorly thought through. There was also much local opposition to the diversion of housing and welfare resources away from existing local communities to workers who were already reasonably well paid and had steady employment. There was also widespread fraud, confusion, and mis-management, a problem compounded by inter-governmental arguments over the role, legitimacy and effectiveness of KW support projects (see Raco, 2007b: pp.47-76). KW support remained a minor part of regional policy until the Thatcher reforms of 1979-1982, when it was abolished.

However, during the 2000s the discourse of the KW has re-emerged within spatial policy, not in response to the demands of migrating employers but as a vehicle for ensuring that through the presence of KWs, public sector labour markets could function effectively and that welfare and social services, and therefore place competitiveness and 'sustainability', could be sustained and enhanced. By the early 2000s it had become increasingly clear to the Labour government that spatial imbalances and inequalities were beginning to have a significant impact on the UK's strongest-performing regions and the national economy more generally. The growth in employment, households, and incomes in London and the South East has fuelled new levels of demand for social infrastructure such as housing and transport. The supply of housing has not kept pace with these demands with low cost or affordable housing, in particular becoming less and less available to a growing range of workers. For example, during the 2000s around 25,000 new homes for rent have been built annually by Housing Associations but 50,000 homes have been lost through the government's Right to Buy scheme in which local authority housing is sold off to tenants. Between 1999-2004 household growth in the UK has consistently outpaced housing unit growth by 59,000 per year and the Barker 
Review in 2004 showed that 14,000 fewer houses were built in London and the South East between 1996-2001 than the government's target figure (Barker, 2004; see figure 1). In 2005, house-building rates were at their lowest in England since 1924 at a time when economic growth was pushing up demand for a range of housing.

Figure 1: Annualised Housing Targets for England, 1996-2001

\begin{tabular}{|c|c|c|c|c|}
\hline & $\begin{array}{lr}\begin{array}{l}\text { Current } \\
\text { Target } \\
\text { annum) }\end{array} & \text { RPG } \\
& \text { (per } \\
\end{array}$ & $\begin{array}{l}\text { 1996-2001 } \\
\text { Household } \\
\text { Projections } \\
\text { (average annual } \\
\text { increase) }\end{array}$ & $\begin{array}{lr}\text { Average past } \\
\text { completions } 1996- \\
2001\end{array}$ & $\begin{array}{l}\text { Difference } \\
\text { between RPG } \\
\text { target and current } \\
\text { completion rate }\end{array}$ \\
\hline London & 23,000 & 25,200 & 13,396 & $-9,604$ \\
\hline South East & 28,000 & 35,600 & 23,680 & $-4,320$ \\
\hline Eastern & 20,850 & 23,600 & 18,987 & $-1,863$ \\
\hline North East & 5,321 & 3,800 & 6,995 & 1,674 \\
\hline Yorks. \& Humber & 14,675 & 12,000 & 14,041 & -634 \\
\hline North West & 12,790 & 12,600 & 18,652 & 5,862 \\
\hline West Midlands & 16,100 & 12,200 & 14,137 & $-1,963$ \\
\hline East Midlands & 13,700 & 15,200 & 14,680 & 980 \\
\hline South West & 20,200 & 21,200 & 16,390 & $-3,810$ \\
\hline England & 154,726 & 161,400 & 140,958 & $-13,768$ \\
\hline
\end{tabular}

(Source: Environmental Audit Committee, 2005: p.7)

The net effect of these trends has been that affordable housing for a range of social groups has become increasingly scarce. Those on low and moderate incomes have found it increasingly difficult to provide for their social needs through the market and this had had significant effects on the sustainability of local and regional labour markets and the provision of welfare services. This has coincided with growing inequalities in pay rates between those working in highly rewarded sectors of the private and public sectors and those in lower paid and increasingly insecure occupations ${ }^{2}$. These inequalities are particularly stark for female workers who earn 18\% less than their male counterparts (and $40 \%$ less in part time employment), many of whom are in the public sector where they make up $64 \%$ of the workforce (Mulholland, 2005).

For the public sector in particular the consequences of these tightening housing markets has been severe. In London in 2001 the Greater London Authority reported that that each of the

\footnotetext{
${ }^{2}$ Government figures show that public sector employment has become increasingly important to economic growth, both directly and indirectly with 650,000 jobs created between 1997-2004 (Philpott, 2005). Whilst overall, public pay has increased during this time, this growth has also been matched by growing inequalities with contracted out staff bearing the cost-saving reforms.
} 
city's public sector services 'had a clearly identified recruitment and retention problem, which is severely undermining service delivery' (2001: p.2). Some schools in the capital were reporting an annual staff turnover of $30 \%$ and other 'essential' public services such as transport companies were reporting turnovers in excess of $70 \%$. In addition, the contracting out of public sector jobs to private sector agencies has been expanding leaving many lower skilled public sector workers vulnerable to reductions in their pay and working conditions at the same time that housing prices had been rising and the availability of any type of housing has become increasingly scarce. The short-term threats to the social and economic stability of London and South East were, therefore, becoming apparent.

During the same period, these development pressures were helping to generate a new regional politics that differed markedly from that of earlier decades. For much of the postwar period the strongest advocates of a coherent spatial policy were public, private sector and Trade Union actors in the Development Areas (see Law, 1980). Yet, during the 2000s, it has been voices in London and the South East that have been calling for more interventionist and expansive spatial development programmes. The Greater London Assembly, for example, now forcefully argues that,

'if London is to maintain its relative competitiveness and attract the required labour not only must transport be improved to make commuting easier but the large scale addition of affordable housing must also be addressed' (2001: p.25).

Its development arm, the London Development Agency, has also called for spatial policy to become more focused on increased housing provision to 'promote the most effective use of the available labour force...[and] addressing both the location and other key characteristics of residential development' (LDA, 2001: p.25). Such calls were part of an emerging regional consensus that argued that so-called 'privileged areas' have not received enough in the way of direct spatial policy investment (see SEEDA, 2004; LDA, 2004).

The London branch of the National Housing Federation summed up this new regional agenda by claiming that 'in order to function properly a World Class city needs to be able to house people on a wide range of incomes' (2004: p.3). This has been echoed in the Mayor of London's call for national government to 'give back' some of the net money paid to the UK Treasury as the city as London: 
'generates more wealth than any other region in the country, contributes more to national finances, and makes a unique contribution to the nation's prosperity. Sustaining London's progress has to be a national priority' (Livingstone, 2004: p.3).

Policy makers and advocates of KW housing support have increasingly cited the example of Aspen in Colorado where, during the 1990s, house price inflation made it more and more difficult for public sector labour markets to function effectively. The city's economic and social sustainability was effectively being undermined and it required a major housing and social infrastructure investment programme by the state and city authorities to remedy its problems. Aspen came to represent 'a stark warning as to what could happen in the UK, and in particular London, if nothing is done to create housing for Key workers' (Salman, 2002: p.1 $)^{3}$.

By the year 2000 a new focus for spatial policy had, therefore, emerged based not on the direct support of producers but the broadening of access to social and collective consumption, particularly housing. The emergence of KW housing support initiatives both reflects and reproduces some of these broader changes and the paper now looks at the new programmes in detail before addressing some of the broader questions that they raise.

The Return of the Key Worker - From the Starter Homes Initiative to the Key Worker Living Programme

The government's first KW programme, the Starter Homes Initiative (SHI) in 1999, targeted a small group of public sector workers in London and the South East. The SHI comprised of two strands. First, it provided $£ 230$ million to Housing Associations to encourage the building of KW homes under shared ownership schemes. Approximately 8,000 homes were offered under the scheme in this way. Second, with a total budget of $£ 20$ million, it provided $£ 10,000$

\footnotetext{
${ }^{3}$ The ski resort of Aspen in Colorado became a much used exemplar that acted as 'Rapid growth in the city during the 1990s caused average property prices to soar to 'twelve times the national average, until $70 \%$ of all private housing was being used as vacation homes' (Salman, 2002: p.1). It was feared that the place would become 'dysfunctional' as it not only lacked community facilities and social infrastructure but also was losing its status as an attractive venue for holidaymakers, thereby undermining its longer term competitiveness. The response from the City and State authorities was to develop radical measures through a series of strong and well-resourced Aspen Area Community Plans in the late 1990s and 2000s (see AACP, 2000) ${ }^{3}$. The scheme has been seen as a success and the community has become more balanced and functional, with a wider range of citizens and workers co-present, although some of the structural problems of market inflation are still causing difficulties and the costs of the scheme are being born by taxpayers outside of the City. It has become a cause celebre for policy-makers and activists and is cited not only for its alleged parallels with fast-growing areas of the UK but also because it exemplifies what can be achieved once the 'problem' of an unbalanced community is recognised and tackled through coherent (and expensive) state investment programmes.
} 
interest-free loans to KWs in the health, education, and policing sectors that could be used to purchase property (see Weaver, 2001). However, as interviewed Department of Communities DCLG officers admitted, the SHI was plagued with difficulties from the outset. It was not well conceived and there was great difficulty in identifying KWs and tackling the structural problems afflicting housing markets, particularly in relation to the lack of housing supply discussed above. The offer of $£ 10,000$ was not enough to make a significant difference to claimants' decisions and the emphasis on prioritising KW housing at the expense of other building programmes meant that it generated localised pockets of house-price inflation whilst doing little to tackle wider shortages. It was poorly advertised and awareness amongst public and private sector players was limited.

Despite its limitations the SHI did, however, surpass its original targets. It was designed to assist 4,000 individuals but over four years it paid subsidies to 10,200, demonstrating a clear latent demand within the region's housing and labour markets. It was also popular with regional actors and local authorities across the South East who began to mobilise KWs as a housing 'priority' in a context where the wider politics of house-building was becoming increasingly fractured and tense (see Bramley and Leishman, 2005). KW programmes could act as a 'quick fix' to the growing crisis in available and affordable housing in a political context in which the construction of housing has been locally unpopular. As one DCLG officer noted in interview this political dividend from the KW focus of policy has made the policy popular "across Whitehall" and during the 2000s the issue of KW housing has become widely perceived as a core part of the funding architecture available for housing development and sustainable community-building.

In 2004 the SHI was, therefore, replaced by a much more ambitious programme known as the Key Worker Living Programme (KWLP). The KWLP assists KWs to purchase a property 'suitable for your household's needs and within a reasonable travelling distance of your workplace' (KWL.co.uk). It consists of 2 principle elements:

- 'Homebuy' - in which equity loans of $£ 50-100,000$ are provided to KWs to enable them to buy houses in the open market

- New Build - in which KWs participate in shared ownership or reduced rental schemes for new homes built by Registered Social Landlords

The two elements are somewhat different in that the first provides direct support to KWs to enter the housing market. There is no provision for any increases in the supply of property. 
Instead, the purpose of Homebuy support is to enable KWs to become home owners, thereby, it is argued, increasing the likelihood of a KW remaining in particular post in a particular place. The wider effects on demand and house prices for other citizens are not considered. New Build, however, is presented as a vehicle for the construction of new affordable housing and a mechanism for the provision of housing to lower paid KWs and/or those unwilling or uninterested in purchasing a property. The DCLG's evaluation of the KWLP's impacts show that between June 2004 and April 2005 3,413 individual transactions were aided by the Homebuy programme (Battye et al, 2006). Of these 1,446 (42.4\%) were in the South East, 1,262 $(36.9 \%)$ were in Greater London and $674(19.7 \%)$ were in the East of England. These figures represent approximately $1-1.2 \%$ of all house purchases during that period, with a calculated 'deadweight' of homes that would been purchased anyway of just $0.5 \%$ of the total. In relation to New Build 836 units were constructed during the same period, with $92 \%$ of them used for intermediate renting.

The KWLP defines KWs in relation to tightly defined sectors and these are outlined in Figure 2. It aims to assist $35,000 \mathrm{KWs}$ by 2010 and by the end of 2005 , it had already provided grants to approximately 10,000 applicants. Half of the KW support since 2004 has been spent on the construction of new houses, thereby having some effect on housing supply.

Figure 2: Selection criteria for the Key Worker Living Programme

\begin{tabular}{|l|l|}
\hline Employment Sector & $\begin{array}{l}\text { Criteria } \\
\text { Work in Greater London publicly funded school; to unable to buy a } \\
\text { suitable home for household needs; be permanent employees; legal } \\
\text { UK residents; household income }<£ 80,000 / \text { year. }\end{array}$ \\
\hline Health & $\begin{array}{l}\text { Must be a permanent NHS employee; household income } \\
<£ 60,000 / y e a r ; \text { priority for nurses, cancer services, diagnostic staff, } \\
\text { mental health professionals, midwives, GPs in under-doctored } \\
\text { areas, chiropodists, physiotherapists, arts therapists, paramedics, } \\
\text { radiographers, pharmacists; all assistance dependent on priorities at } \\
\text { Strategic Health Authority level according to local vacancies }\end{array}$ \\
\hline Police & $\begin{array}{l}\text { Police officers in post }>6 \text { months; only those in priority posts of } \\
\text { communications officer, scientific support teams, crime analysts, } \\
\text { station reception officers, civilian gaolers }\end{array}$ \\
\hline Prison Service & $\begin{array}{l}\text { Applications must be in one of the following disciplines: prison } \\
\text { officer, nursing staff, operational support grades, industrials, or } \\
\text { instruction officers. In addition applications must be working in } \\
\text { identified institutions in London and the South East of England. }\end{array}$ \\
\hline Probation Service & $\begin{array}{l}\text { Permanently employed: senior probation officers, probation } \\
\text { officers, probation service officers, trainee probation officers. }\end{array}$ \\
\hline Planners & $\begin{array}{l}\text { Those in London local authority planning offices from Level 1 to } \\
\text { Level 1V }\end{array}$ \\
\hline
\end{tabular}


The KWLP is directed by the DCLG and it has taken a binary role of on the one hand overseeing the strategic dimensions of the programmes whilst at the same time taking on, what one respondent referred to as a 'micro-management' role in which civil servants involve themselves in day-to-day negotiations over particular projects. The Key Worker Housing Branch of DCLG is responsible for the development and implementation of the KWLP and its priorities are reflected in the branch's location in the Sustainable Communities Directorate of DCLG and the Affordable Housing Division. Public service managers have been at the forefront of demands for their employees to be living within a short distance of their work.

The KWLP is being implemented in three regions - the South East, London and the Eastern Region. Within these there are 14 identified Action Zones in which DCLG identifies and works with local stakeholders and project managers. These include individual employers, such as prisons and hospitals and local delivery agents such as Local Education Authorities and local Policing Boards. In addition Zone Agents have been appointed to market the programme, administer the Homebuy element, and provide a one-stop-shop for workers (Battye, et al, 2006). Their purpose is to act as a link between clients and providers and use their local knowledge to make policy implementation more effective in particular places. The deployment of KW housing resources is conditional on Regional Housing Boards (RHBs) requesting the implementation of the programme in their area ${ }^{4}$ Crucially, RHBs have to decide on their own priorities, of which KW housing is a part. Their money is provided by DCLG on a rolling 2-year basis. Where they ask for KW support, this money is directed away from other expenditure programmes so that the contestation over resources comes at the regional level where problems and priorities for action are established and determined. As an DCLG officer stated, "it is not for us to say they should have KW support... it is up to them".

\footnotetext{
${ }^{4}$ Regional Housing Boards were established as part of the Sustainable Communities Plan in 2003 to ensure that housing policies would be better integrated with the regional, spatial, transport, economic, and sustainable development strategies.
} 
'the government is committed to improving the quality of public services and provision of accommodation through Key Worker Living scheme remains a key part of the strategy for achieving this... it should address areas where there are recruitment and retention problems' (paragraph 7).

The minimum levels of funding that the government would 'like' the RHBs to allocate for KW housing in the London, South East and Eastern Regions are laid out in figure 3. The South East RHB plans to spend 25\% of its Housing Pot on KW housing in this period and other RHBs have similarly been allocating KWs increased provision (see South East RHB, 2005a: p.2).

Figure 3: Minimum levels of funding to be spent on the KWLP (Emillion)

\begin{tabular}{|l|l|l|}
\hline Region & $2006 / 2007$ & $2007 / 08$ \\
\hline East of England & 31 & 32 \\
\hline London & 199 & 204 \\
\hline South East & 96 & 99 \\
\hline
\end{tabular}

(Source: Hill, 2004: paragraph 7).

At the same time the budget for the KWLP has increased from £690million to $£ 725$ million, reflecting the on-going nature of the KW problem and the programme's increasingly high profile and branding. KWLP managers are increasingly using GIS technology to 'map' where employers are located and how this relates to the local housing demand. The use of such technologies is indicative of a more resource-intensive and well-organised strategy as well as the wider spatial imaginations that underpin the programme. DCLG are in the early stages of developing these forms of analysis and it is expected that they will inform the distribution of resources in future policy rounds. 
The KWLP has therefore begun to have some effect on housing provision for public sector workers has become an increasingly important element of housing policy in London and the South East. It is no longer a small-scale initiative but has taken on a high degree of practical and symbolic/political significance in a context where policies to deal with the lack of housing supply have been relatively ineffective. It is indicative of the ways in which spatial policy has become an active social policy, in which broader concerns with issues such as the availability of housing and the efficient operation of other social-welfare services and their relation to place competitiveness have taken centre stage. It involves new forms of selection and support that provide access to state resources on the basis that a particular individual's skills and capacities are seen as essential to the functioning of public services and ultimately the competitiveness of particular places. However, its development and implementation has met with some resistance and the remainder of the paper now focuses on the politics that has underpinned the new agendas.

\section{The politics of key worker housing}

The introduction of the KW support schemes has not been without controversy. In many ways they have come to represent what Clarke (2005: p.459) defines as 'a political project to manage the dynamics of homogeneity and heterogeneity; [and] to define what forms of diversity are recognised and how they are to be governed'. Such political projects require specific 'problems' to be identified and addressed and boundaries of entitlement to be drawn between the included and the excluded. This raises particular problems for worker representatives who are charged with the management of competing and contrasting claims between different sets of workers. This section explores some of these emerging debates over KW policy and highlights the implications for the wider politics of spatial policy design and implementation.

The first set of tensions relate to the broader rationalities underpinning the programme and the extent to which the identified 'problem' of KW shortages in the public sector can be traced, as the Labour government argues, to the issue of housing affordability. As Buchan (2000) argues the recruitment (and retention) of public sector workers is a complex policy area. Many of the problems faced by welfare service managers in the UK (and western Europe more generally) relate to the large-scale retirement of the 'baby-boom' generation of workers who were recruited during the period of welfare state expansion in the 1960s and 1970s (see Education and Employment Select Committee, 2001). Such workers now need 
Alongside some of these broader concerns, KW programmes have also generated significant political tensions in the ways in which they have been implemented. Processes of KW definition have been particularly controversial. The DCLG argues that decisions over definitions are always negotiated. In the words of one DCLG interviewee, "everybody is a KW. We don't define who a KW is but we work with stakeholders to identify who, in what circumstances needs assistance as a KW'. DCLG sets the 'framework' for discussions around KW housing and identifies three key sectors, health, education, and community safety, that the government believes should be prioritised by local and regional policy makers. In health care, for example, respondents argued that in the early 2000s London NHS managers called for KW assistance to be given to cancer specialists, owing to a particular shortage, a request that DCLG supported and implemented. Similarly new Community Safety Officers have been identified by the Home Office as $\mathrm{KW}$ as an expanding area of recruitment. As one DCLG officer remarked, "we get lobbied constantly to include new workers from TUs, government departments and everybody else...we've only got so much and we have to make decisions in consultation with others".

And yet other sources indicate that this process of 'negotiation' is heavily weighted towards the views and expectations of Central Government. Committee Minutes reveal that regional bodies such as the South East RHB have started to consider the processes through which there could be 'a broadening of the definition [of KW] to include other essential workers according to varying local circumstances' (South East RHB, 2005b: p.2). The government's focus on KW, they argue, is inherently limiting and undermines the legitimacy of housing support for other non-KWs. In addition, minutes of the Board Meetings of the London RHB show a growing unease over the ways in which the KWLP is skewing housing spending away from high need groups. Investment in socially rented housing in London during the period 2004-2006 only 
produced 10,000 socially rented homes, way below the target figure of 21,000 . This $46 \%$ development rate is below the $70 \%$ target laid out in the Mayor of London's London Plan (Greater London Authority, 2004). For those on the Board this lack of social housing construction was a direct 'result of the Minister's decision that additional investment in London was to be directed at key worker housing' (London Housing Board, 2005: p.3). Centrally-directed reprioritisation was criticised for its impacts on the city's housing stock and for the limitations it has placed on the powers and decisions of regional actors.

Others have also been critical of what they see as central government 'interference' in regional policy-making. The South East Regional Housing Strategy 2006 Onwards (South East Regional Housing Board, 2006) explicitly criticises the KWLP arguing that it uses up 33\% of the regions funding for affordable housing, a level that is 'disproportionate to other needs within the region and means reduced allocations for other groups who are in similar or greater need' (p.44). In order to 'address better the needs of the region' (p.45) more the Strategy calls for more evidence-based policy and a greater focus on the needs of a broader range of citizens. It states that 'a wider definition of key workers is needed to ensure the provision of essential local services and economic viability of housing market areas' (p.46). These debates over the rights and wrongs of KW housing betray a wider series of tensions over whose responsibility it should be to decide on KW (and non-KW) housing policy and whether this should be done at the national, regional or local scale.

These tensions have also been evident in the processes though which particular workercitizens are ascribed with different needs, aspirations and socio-economic value. For instance, KWLP assistance is only available to 'permanent employees', not to workers on flexible, short-term contracts. For those involved in sectors such as education this has been institutionalised into a competitive, relational 'points system' that allocates points to particular types of worker (see Figure 4 for the example of the points system in the education sector). However, across the public sector, the contracting-out of employment has changed the modus operandi of labour markets and has created a new class of non-permanent employees. The KWLP's restrictions therefore exclude contracted-out workers who are often in urgent need of housing assistance. In some cases new micro-boundaries on inclusion and exclusion have been drawn within organisations. The Metropolitan Police, for instance, stipulate that its Station Officers are eligible for KW support with the exception of those in three London Police Stations in which front-desk work has been already contracted out. For 
Figure 4: The Key Worker Living Programme: Qualification criteria for those in the education sector

"the essence of contracting out is that providers provide the service at a cheaper rate. How they pay their staff and what assistance they give them with housing or transport costs is a matter for them...there is nothing that we can do about it. It is a cost to be met by the private sector as a part of their contract. Any interference from us would skew the competitive bidding process".

This 'skewing' of the competitive principle would mean, in effect, that public sector resources under schemes such as the KWLP would be used by private sector agencies to subsidise their costs. The implementation of the new programmes only serves to exacerbate the existing differences between different workers.

Under the KWLP assistance of up to $£ 100,000$ is available to those who are:

- Teachers in Greater London

- Unable to buy a home suitable for their household needs within a reasonable travel to work area of their employment

- Permanent employees

- Have indefinite leave to remain (excluding key workers from the EU)

- Have household income that does not exceed $£ 80,000$ per annum

- Sell their existing property if they own one

- Work in a school that is in receipt of public funds

In addition applicants must score a minimum of 7 points to qualify from the following:

- $\quad$ Advanced Skills Teacher -5 points

- Teach First Grades -5 points

- Commissioner's Teacher -2 points

- $\quad$ Fast Track Teachers -2 points

- Shortage subject teachers -2 points

- Head teacher, Deputy/Assistance Head teacher

- Management/Leadership

- Extra responsibilities

- Challenging schools - 1-5 point depending on severity of problems

Those not receiving enough points may still qualify for $£ 50,000$ Open Market Homebuy payments.

Source: DCLG (2006)

Beyond these questions of selection, KW support schemes have also sought to bring about other changes. One implicit objective is to instil market values and a market-driven 'stakeholder politics' into the governmentalities of KWs. Rising house prices are presented as beneficial to individuals and the KWLP encourages workers to become consumers in the housing market - indeed, it offers a vision in which sustainable, active citizenship is closely tied to home ownership. Aside from the broader effects such changes may have on $\mathrm{KWs}^{\prime}$ 
perceptions of citizenship, there is also the potential of creating dependent relationships between KWs and their employment posts. The KWLP requires KWs to remain in their jobs, otherwise they are subject to a process of 'clawback'. If they leave their occupation or their region they forfeit their right to $\mathrm{KW}$ assistance and have to repay the sum they have borrowed or the percentage of the value of their home that the equity loan purchased, whichever is the largest. In the case of shared ownership the property must be purchased or the KW will be forced to leave (see Battye et al, 2006: p.22). Clawback has only been introduced under the KWLP and is designed to reduce the flexibility of public sector KWs and lock individuals into dependent relationships with their work. Employment is, therefore, being linked not only to remuneration through the payment of wages but also to a worker's broader quality of life and access to the means of social consumption. Over time this may alter the balance of the worker-employer relationship, with bargaining power being transferred to the latter.

The attachment of state resources to KWs has also had an effect on the ways in which other actors, such as builders and developers operate. In the absence of strong regional planning agencies, sustainable communities are to be constructed by private developers working in partnership with public sector organisations. There is evidence that some developers are seeking to take advantage of the funding opportunities offered by the KWLP at the expense of non-KW, affordable housing. The location and scale of house-building in the South East of England has become a fiercely contested political issue at the local and regional scale (see Pacione, 2004). Despite the government's emphasis on 'balancing housing supply and demand', the construction of new houses has generated significant levels of protest on environmental, social and economic grounds (see, for example, English Heritage, 2004) and rates of house building have remained relatively low. As a number of interviewees admitted, constructing homes for KWs has been less controversial and has represented a mechanism through which developers and state agencies have been able to promote house building whilst limiting criticism. As one KW project manager noted (emphasis added),

"the type of people who are KWs are those who are seen as 'good' people. For the mortgage companies and development industry they are safe bets with steady incomes and they are unlikely to lose their jobs. For developers and planners they are good because they are popular with existing residents - you know they are 'good' people who deserve assistance and can help raise the profile of the neighbourhood - they are everybody's idea of successful mixed housing and are a part of any community". 
On a broader canvass, DCLG respondents argued that thus far the KWLP had not generated significant regional tensions across the public sector. As a DCLG officer commented in interview "the fact that it is the RHBs that request $K W$ support and that the resources are not coming out of other budgets, there is lack of argument between regions". There was also some evidence that the programme is being considered in other regions where spatial inequalities have grown rapidly since the mid 1990s and public services in some parts of the country are coming under staff recruitment and retention pressure. In some places outside of the East and South East local agencies are taking it upon themselves to build KW homes. In Bath, for example, a local Housing Association has recently started selling off some of its expensive town flats in order to raise money for KW housing so that the community can become more balanced and functional (see Morris, 2005). Such local initiatives provide evidence that the concept and delivery of KW policy looks set to remain high up the housing agenda.

However, the spatial selection inherent in these KW schemes has not gone unchallenged. The National Housing Federation (2005), amongst others, has increasingly argued that it is in rural areas across England, not just in the South East, that the problems of sustainable community building are most acute. The Labour government's unwillingness to restrict or disincentivise the purchasing of second homes, allied to restrictive rural planning and the polarised nature of rural labour markets has undermined the sustainability of many rural communities. The Federation, along with others, now explicitly calls for an extension of the KWLP to make specific provision for rural workers as their absence both reflects and reproduces reductions in public service provision and community sustainability. This spatial 
selectivity in the programme reflects the long-standing tension in spatial policy concerning the drawing of boundaries and the inclusion and exclusion of particular areas.

Key worker housing and the wider politics of state selection

The principle of selectivity also creates problems for those who represent policy recipients. The national TUC, for example, is officially opposed to the concept of the KW and argues that rather than defining particular groups and supporting them through housing subsidies, more affordable, public sector housing should be made available for the benefit of all workers. A representative commented in interview that,

"the fundamental root of the KW debate is about housing and good quality and available pubic housing should be a right of all workers...the KWLP is just a sticking plaster what is required is more supply in the housing market".

Other Trade Union representatives were also critical. One interviewee from the UK's biggest TUs argued,

"we simply do not accept the concept of the Key Worker for four reasons: it creates divisive definitional problems; vital jobs are excluded; it frames debates over housing and worker support; and it is based on a series of assumptions about what workers do".

Others highlighted the relatively arbitrary nature of KW selection and pointed to anomalies in which district nurses and teachers qualify for support but health care and teaching assistants do not even though their roles have become increasingly intertwined. In addition some sets of workers, such as home care workers (who are often female) are so poorly paid that schemes to assist with the purchase of a house are unrealistic and potentially damaging if they are used to justify public-private sector pay differentials. Other union representatives highlighted some of the practical problems that have beset the KWLP. Implementation of the programme has been inherently divisive and this was causing feelings of resentment amongst workers excluded from assistance. This was being compounded by a confusing diversity of information and mis-information surrounding complex questions in eligibility and accessibility and concerns over the transparency of the support being given to some groups of workers.

However, this scepticism over KW policy was not shared by all TUs. Some teaching unions representatives, for example, expressed qualified support for KW definitions and 
programmes. In part this reflected an instrumental rationality, in that KW programmes could assist in the retention and recruitment of staff in the London area. However, there was also a clear social/cultural rationale in that, in one respondent's words,

"when you become a teacher you have an expectation of good housing and that you will have a sufficient income for a good quality of living and a reasonable lifestyle...you need a place to relax and to go home and work...teachers need this in a way that other groups of workers do not, it is all about aspirations and teachers' aspirations are higher than other groups and this needs to be reflected in government policy".

It was argued that without such support teachers, as skilled individuals, will find themselves other jobs, particularly in a context where the costs of housing have increased. Owner occupation is still cited as a minimum requirement for teachers as "council housing is not what a teacher aspires to". Some of the teaching unions have, therefore, called for the programme to be extended, particularly at the top end of the scale for head teachers whose skills are needed in 'problem' areas such as inner cities and whose presence in such places the state should seek to support and encourage.

What is of particular interest here is the way in which relational classifications of citizenship, underpinned by resource transfers between different groups, institutionalise and reinforce divisions between types of workers in different places. Workers and worker representatives are asked to justify why their workers should be entitled to specific forms of support at the same time as others are excluded from it. This political process of inclusion/exclusion has taken on both a social and spatial character with tensions arising over the different 'needs' of different classes of workers and different regional and local circumstances. One teaching union representative for instance, noted that,

"you just don't get problems filling classes with classroom assistants or getting secretaries. These people are local, they are happy with their lot and happy to do a local job, there's never a problem filling vacancies. For teachers coming into an area from outside it is a different story. They expect and deserve a house of their own and their skills are needed in these localities".

In a context of increasingly scarce housing resources in the London area the relational divisions between different groups take on even more significance. Low skilled, often parttime workers are being ascribed with particular roles, needs and aspirations. These, it is argued, are relationally different from those of more 'professional' citizens whose expectations and importance to the functioning of communities are greater. It should also be 
noted that problems of affordability also impact greatly on low skilled workers in the private sector.

Within the interviews it was also noted that there were growing spatial divisions that were impacting on the efficiency of particular spatial economies and sustainable communities. For example, London-based representatives of some TUs explicitly argued for extra provision to be made for London-based KWs. As one local activist noted "it is simple - there simply is no cheap housing anywhere in London, period. It is just not the same elsewhere and I'm delighted that something is being done about it". However, others noted that the issue of KW assistance was creating some tensions across the union movement, particularly in relation to the boundaries where KW programmes start and end. As one interviewee noted "it is at the cliff edges that we have problems, with those on the wrong sides of the divide being unhappy about what London-based workers are getting". Others referred to the regional differences that were emerging over what was perceived as favouritism on the part of government to the issues affecting public sector workers in the capital. In other 'hotspots' of development, such as North Yorkshire and some parts of the M4 corridor to the west of London the absence of KW support programme has been criticised for being unfair. This is a particular problem for many public sector employers as many public sector workers are on nationally-agreed pay scales and are therefore potentially footloose, as they may have the option of taking up similar positions, with lower costs of collective consumption, elsewhere.

Other interests, such as the business community in London and the South East have in general been supportive of the rolling out of the KWLP. The CBI's official policy on KW housing is that it represents a 'key business issue' and that labour markets are becoming increasingly uncompetitive and dysfunctional owing to a lack of housing supply. Digby Jones (2005), the Director General, for example, told the CBI Congress in 2005 that,

"I want a society where the lower-paid postal workers, nurses and teachers, especially south of Birmingham can afford a house. They can't at the moment...we are going to have people not being able to live in a home of their own in Great Britain".

This focus on the needs of lower paid, public sector workers is presented as a problem for the efficient functioning of businesses as public and private sector labour markets are fundamentally interrelated. At the same time, it was further argued that, 
"we are not going to be a place where overseas investors are going to want to invest. We've always been the location of choice in Europe for the Boardrooms of Detroit, Tokyo, Johannesburg, Frankfurt, to create the wealth, pay tax, build schools and hospitals. I want that to continue. But if they can't get the labour because there's nowhere to live they won't come".

The CBI's focus however, is on a more holistic agenda in which the planning system is freed up and made less restrictive in order to allow the house-building industry to deliver all the homes required. Notwithstanding the environmental tensions that such an agenda would create (see the Environment Agency, 2005) the expectation is that "the law of supply and demand will work" if government provides the right incentives and opportunities. The apparent tensions involved in supporting market-based solutions, whilst at the same time backing direct public intervention through programmes such as the KWLP are not readily acknowledged. Both the TUC and CBI do, however, see KW housing programmes as a shortterm solution for wider market and planning failing, even if the former also see the policy as part of a wider affordable housing programme.

However, there is also evidence of growing disquiet over the potential knock-on effects of KW housing support for housing policy. During the mid 2000s organisations such as Association of London Government were arguing that there needed to be a new balance between the needs of KWs and existing 'social housing' projects. As one of its statements succinctly puts it,

'although we are seeing a welcome increase in government investment in housing, this is limited and mainly targeted at homeless households and certain public sector workers. It is unlikely to make a significant difference to the average London worker' (ALG, 2004a: p3.)

Their own surveys of those involved in the social housing sector in London indicated, for example, that in many communities 'there is a risk of key workers and those needing social housing being perceived as 'deserving' and 'undeserving' respectively' (ibid, p.5). Because of this divisiveness, housing policy should therefore 'prioritise social rented housing and increase the proportion of social rented rather than key worker homes' (ALG, 2004b: p.2).

In terms of the delivery of the KWLP there are also growing complaints that it helps those who are best able to help themselves. Once again the ALG (2004b: p.3) argue that 'the current definition of key workers is too narrow, and should be expanded to recognise the many groups of workers who find it hard to access housing'. They go on to suggest that the scheme should be 
linked to specific employment centres and a closer understanding of the needs and priorities of KWs. Such criticisms echo those made by local authorities and communities in the postwar Development Areas in which the legitimacy and ultimately the effectiveness of KW programmes became increasingly questioned (see Raco, 2006). As the KWLP expands and is perceived to become more qualitatively and quantitatively important, so its political repercussions in fast-growing, target areas such as London and the South East can expect to become more significant.

Overall, then the re-establishment of KW support programmes has been embedded within a changing wider politics of spatial development. As programmes have become more substantive, in discursive and material terms, so debates at different scales and in different places have intensified and, in many ways, become more divisive. This politics, in turn, exemplifies the wider processes inherent in the changing nature of spatial policy and the broader tensions associated with the principles and practices of selection. It also raises questions over the future of spatial policy and it is to these that the conclusions now turn.

\section{Conclusions}

This paper has examined the discourses, rationalities, and politics surrounding the introduction of KW housing support in parts of England, within the context of the Labour government's new spatial policy agendas. It has argued that the new schemes reflect and reproduce broader changes in policy thinking and practice and involve a shift away from direct support to improve the productive capacities of firms within the regions to a greater concern with how forms of social consumption can be made available to the 'right types' of 'valuable' workers and citizens. In recent academic and policy writing much attention has been given to the ways in which social and spatial policy can influence the locational decisions of individual entrepreneurs and the so-called Creative Class (see for example, Florida, 2002; Peck, 2005). However, this paper has argued that similar ways of thinking characterise policies towards other groups of workers in particular contexts, such as public sector key workers in fast-growing regions of England. In the name of sustainability and sustainable community-building, new policies have been established to assist selected, defined groups of workers by providing with the means of social reproduction, a better quality of life, and access to housing in ways that meets their (relatively high) socio-economic aspirations. 
There are also implications for broader conceptualisations of spatial policy that are currently popular in the planning, geography and regional studies literatures with their emphasis on state selectivity and spatial selection, premised upon the argument that 'those places that support the basic structure of the state and its objectives are privileged in the accumulation strategy' (Jones, 1997: p.849). The paper has argued that the new agendas of selectivity do not represent a simple top-down exercise in which rationalities are developed by (nation) states and implemented in a thought through and strategic fashion. The KW support programmes have, in large part, been forged in a reactive way, in response to political pressure from development agencies in fast-growing areas of the country, complaints from employers about skills shortages, criticisms from trade unions over the pay gaps between public and professional private sector workers, and more general criticisms over the failures of the planning system to ensure the adequate provision and accessibility of the means of social consumption. The new spatial policy is, in part, about selecting favoured regions as the subjects and objects of broader, accumulation strategies. But it is also concerned with mollifying the negative externalities and effects of such growth and the consistent failure on the part of post-war governments to invest sufficient resources in the public infrastructure of those same regions. Indeed, the emergence of KW programmes makes clear the limitations of existing housing and planning policies that rely on the private sector and local quangos to build enough housing for the right groups of people in the right places, at the right times in order to meet the wider objectives of policy. 
The paper has also highlighted the processes involved in governing these new selective forms of welfare provision and the complexities of defining and drawing boundaries of entitlement. It is clear that despite the 'partnership' nature of decision-making processes surrounding KW policy, Central Government, through DCLG, has played the most important role in shaping the priorities of local and regional actors. Further research could look at how such processes operate, who it is that is selected as policy subjects and objects, and what such processes tell us about wider conceptions of citizenship and the 'value' of particular groups to sustainable community-building. The paper has focused on public sector workers but similar themes and processes operate in relation to the private sector and which skills are deemed necessary to economic growth and sustainable community development and how such workers can be created or imported. The analysis here has indicated that better organised and politically mobilised groups are able to re-shape the boundaries of welfare entitlement to their advantage. A new politics of consumption, along these lines, has the potential to generate new forms of inequality in the future between those whose needs are well articulated and reflect broader policy ambitions and those whose who do not.

\section{Acknowledgements}

The research material used in this paper is drawn principally from two research projects, one funded by the British Academy (Grant Award: SG: 40053 'Key Worker Programmes, Changing Modes of Citizenship and Regional Development in Post-war Britain 1945-70') and the other under the Engineering and Physical Sciences Research Council's collaborative research programme on 'Sustainable Urban Brownfield Regeneration: Integrated Management' (grant number GR/S148809/01).

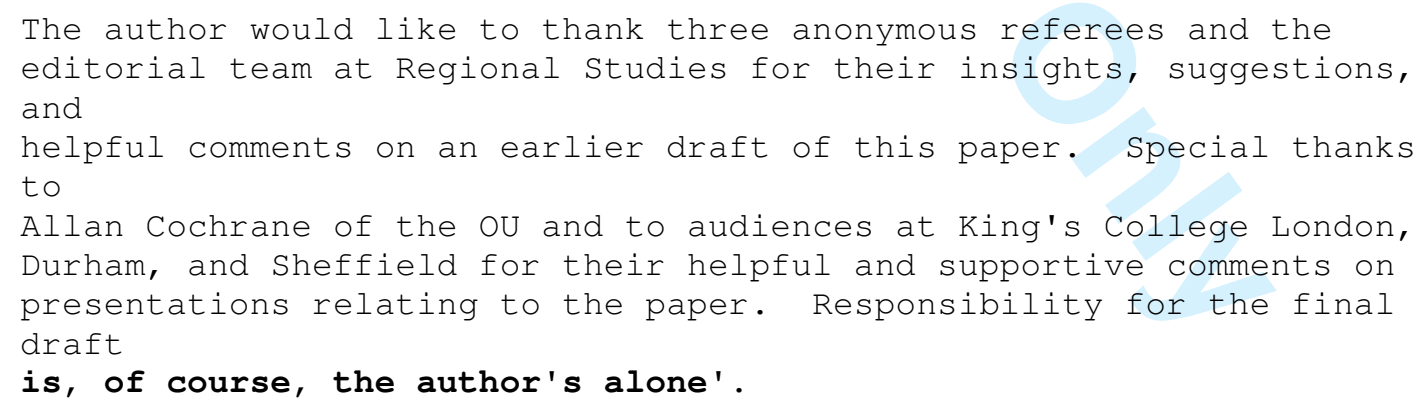


References:

Allmendinger, TJ (2006)

Association of London Government (2004a) Through the Eyes of Londoners: Housing and Communities, ALG, London.

Association of London Government (2004b) Response to the London Housing Strategy Consultation, 22 July 2004, ALG, London.

Barker, K. (2004) Delivering Stability: Securing Our Housing Needs, HMSO, London.

Battye, F., Bishop, B., Harris, P., Murie, A., Rowlands, R., and Tice, A. (2006) Evaluation of Key Worker Living - Final Report, Department for Communities and Local Government, London.

Bramley, G. and Leishman, C. (2005) Planning and housing supply in two-speed Britain: Modelling local market outcomes, Urban Studies 42, p2213

Brenner, N. (2003) Glocalisation as a state spatial strategy: urban entrepreneurialism and the new politics of uneven development in western Europe, in J. Peck and H. Wai-chung Yeung, eds., Remaking the Global Economy - Economic-Geographical Perspectives, Sage, London, pp.197215.

Brown, G. (2006) Budget Statement 2006, Speech to House of Commons, found at: http://www.hm-treasury.gov.uk/budget/budget 06/bud bud06 index.cfm, 22 March.

Butler, T. and Robson, G. (2003) Negotiating their way in: the Middle Classes, gentrification, and the deployment of global capital in a globalising metropolis, Urban Studies, 40, 9, 17911810 .

CABE (2006) $\ldots$

Clarke, J. (2005) New Labour's citizens: activated, empowered, responsibilised, abandoned?, Critical Social Policy, 25, 447-463.

Cochrane, A. (2003) The new urban policy: Towards empowerment or incorporation? The practice of urban policy in R. Imrie and M. Raco (eds.) Urban Renaissance? New Labour, Community, and Urban Policy, Policy Press, Bristol, pp.223-234.

Cochrane, A. (2006) in Tewdwr-Jones

Department of Culture, Media and Sport (2006)

The Economist (2006a) Immigration - pick and mix, March 11, pp.28-30.

The Economist (2006b) Europe's labour mobility - when East meets West, February 11, p.41.

Education and Employment Committee (2001) *** 
English Heritage (2004) A Welcome Home - A Sense of Place for a New Thames Gateway, English Heritage, London.

Environment Agency (2005) Creating a Better Place - the Environment Agency's Assessment of the Environment in South East England, Environment Agency, London.

Environmental Audit Committee (2005) Housing: Building a Sustainable Future, HMSO, London.

Florida, R. (2004) Cities and the Creative Class, Routledge, New York.

Greater London Assembly (2004) The Case for London - London's Loss is No-one's Gain, GLA, London.

Greater London Authority (2001) Affordable Housing in London: A Report for the Greater London Authority, Great London Authority, London.

Greater London Authority (2004) The London Plan - the Mayor's Spatial Development Strategy for Central London, GLA, London.

Hill, K. (2004) Letter to Regional Housing Boards from Rt. Hon. Keith Hill MP, ODPM, London, February.

Imrie, R. and Raco, M. (2003) Community and the changing nature of urban policy, in R. Imrie and M. Raco (eds.) Urban Renaissance? New Labour, Community, and Urban Policy, Policy Press, Bristol, pp. 3-36.

Jones, M. (1997) Spatial selectivity of the state. The regulationist enigma and local struggles over economic governance, Environment and Planning A, 29, 831-864.

Jones, D. (2005) Speech to CBI Congress, Birmingham, cited on Channel 4 News, Tuesday 4 October.

Law, C. (1980) British Regional Development Since World War I, Methuen, London.

Livingstone, K. (2004) 'Foreword' in Greater London Assembly (2004) The Case for LondonLondon's Loss is No-one's Gain, GLA, London, pp.3-4.

London Development Agency (2001) Annual Report, 2000/2001, LDA, London.

London Housing Board (2005) Minutes of a Meeting of the Board - Funding Recommendations for 2006-2008, London Housing Board, London, 28 February.

Morris, S. (2005) Sale of premium flats in Bath will house key workers, 28 February, found at: www.SocietyGuardian.co.uk, p.1.

Mulholland, H. (2005) No quick fix for gender pay gap, The Guardian, 9 September.

National Housing Federation (2005) Evidence to the Affordable Rural Housing Commission, BBC News, November 27. 
Office of the Deputy Prime Minister (2003) Sustainable Communities: Building for the Future, HMSO, London.

Office of the Deputy Prime Minister (2004) Planning Policy Statement 1: Planning for Sustainable Development, HMSO, London.

Office of the Deputy Prime Minister (2005) The Mixed Communities Initiative - What is it?, HMSO, London.

Office of the Deputy Prime Minister (2006) The Key Worker Living Programme - Qualification Criteria, HMSO, London.

Pacione, M. (2004) Where will the people go? - assisting the new settlement option for the United Kingdom, Progress in Planning, 62, 73-129.

Peck, J. (1996) Work-Place: The Social Regulation of Labor Markets, The Guilford Press, New York.

Peck, J. (2005) Struggling with the creative class, International Journal of Urban and Regional Research, 29, 740-770.

Philpott, J. (2005) Pay Gap Favours Public Sector Workers, Chartered Institute of Personnel \& Development, London.

Raco, M. (2006) Moving workers with the work: State selection, key workers and spatial development policy in post-war Britain, Geoforum, ****

Raco, M. (2007a) in D. Gibbs and R. Krueger (eds.) ${ }^{* * *}$, in press.

Raco, M. (2007b) Building Sustainable Communities - Spatial Policy, Place Imaginations and Labour Mobility in Post-War Britain, Policy Press, Bristol.

Salman, S. (2002) Looking abroad for the solution, The Guardian, February 20.

Savage, M., Bagnall, G. \& Longhurst, B. (2005) Globalisation E Belonging, Sage, London.

SEEDA (2004) Regional Economic Strategy for South East England, 2002-2012, SEEDA, Guildford.

South East Regional Housing Board (2005a) South East Regional Housing Strategy, 2004/05, 2005/06, Government Office of the South East, London.

South East Regional Housing Board (2005b) Minutes of Meeting Held at Government Office for London, 28 February.

Weaver, M. (2001) Loans top-up for Starter Homes Initiative, The Guardian, 5 September.

While, A., Jonas, A., and Gibbs, D. (2004) The environment and the entrepreneurial city: Searching for the Urban Sustainability Fix in Manchester and Leeds, International Journal of Urban and Regional Research, 28, 549-569.

Whitehead, M. (2006) $* * *$ 